\title{
The Mandatory Nature of Online Learning During COVID-19: A Comparative Study of the Experience of Three Universities
}

\author{
Yana Goncharova \\ yana.goncharova@unicampania.it / University of Campania “Luigi Vanvitelli” \\ Tatyana Savchenko \\ savchenkor@yandex.ru / Pyatigorsk State University \\ Olga Sheveleva \\ olga431531@yandex.ru / Dubna State University \\ Iuliia Zubcova \\ julia.zubtzova@ya.ru / Pyatigorsk State University
}

Recepción: 1/10/2020 Aceptación 30/10/2020

\begin{abstract}
This paper is devoted to the comparative analysis of three online learning platforms used by three universities (Dubna State University and Pyatigorsk State University in Russia and University of Campania "Luigi Vanvitelli" in Italy) for the forced adoption of online learning during the COVID-19 pandemic. The advantages, defects and restrictions of each learning platform are analyzed along with the factor of human error and incompetence while using the platforms. It was found that it was difficult to establish the authorship of the tasks performed, to check the real attendance and level of involvement during online lectures, and to ascertain students' identity without violating laws on personal data and privacy. What is more, the participants of the educational process demonstrated their lack of experience and technical skills to work with the platforms, and their lack of motivation and self-discipline. In accordance with the data received and analyzed in this research, a list of recommendations and technical specifications required is offered. This research is useful for government institutions, universities, academic staff and students working or planning to start working with online learning instruments.
\end{abstract}

KEYWORDS: online learning / learning platforms / online learning technologies 


\section{El carácter obligatorio del aprendizaje en línea durante el COVID-19: estudio comparativo de la experiencia de tres universidades}

RESUMEN. Este artículo está dedicado al análisis comparativo de tres plataformas educativas en línea utilizadas por tres universidades (la Universidad Estatal de Dubná y la Universidad Estatal de Pyatigorsk en Rusia y la Universidad de Campania “Luigi Vanvitelli” en Italia) para la adopción forzosa del aprendizaje en línea durante la pandemia del COVID-19. Se analizan las ventajas, los defectos y las restricciones de cada plataforma educativa junto con el factor de error e incompetencia humana durante el uso de las plataformas. Se comprobó que era difícil establecer la autoría de las tareas realizadas, comprobar la asistencia real y el grado de participación durante las clases en línea y averiguar la identidad de los estudiantes sin violar las leyes sobre datos personales y privacidad. Además, los participantes del proceso educativo demostraron la falta de experiencia y habilidades técnicas para trabajar con las plataformas y la falta de motivación y autodisciplina. De acuerdo con los datos recibidos y analizados en esta investigación, se ofrece una lista de recomendaciones y especificaciones técnicas necesarias. Esta investigación es útil para las instituciones gubernamentales, las universidades, el personal académico y los estudiantes que trabajan o planean empezar a trabajar con instrumentos de aprendizaje en línea.

PALABRAS CLAVE: aprendizaje en línea / plataformas educativas / tecnologías educativas en línea 


\section{INTRODUCTION}

It is with good reason that the 21 st century has become the age of online learning. The paradigm shift in the education system was caused by the introduction of information and communication technologies (ICT) into the academic activities. These technologies available to the popular majority in the developed world have made the educational process as open and transparent as never before in human history. Scholastic institutions across the globe create online courses; give free access to e-libraries and database; and design or buy platforms to introduce online lectures, workshops and other forms and types of activities. These platforms help to place the teaching process, partially or completely, in an online environment and to create more flexible educational conditions based on the best traits of traditional face-to-face learning.

There are numerous definitions and variations of the term online leaning, from the simplest to those having legal effect. There are several of them:

- E-learning is a system of learning that uses electronic media, typically over the internet (from Oxford Learner's Dictionaries).

- Online education is a flexible instructional delivery system that encompasses any kind of learning that takes place via the Internet (from Encyclopedia.com).

- Online educational technologies are understood as educational technologies realized mainly with the help of information and telecommunication technologies upon condition of indirect (remote) or partially indirect interaction between students and teachers (from the Federal Law No. 273-FZ of December 29, 2012 "On Education in the Russian Federation").

Within the context of this research, we use the following working definition shared by many contemporary researchers: Online learning is defined as "learning experiences in synchronous or asynchronous environments using different devices (e.g., mobile phones, laptops, etc.) with internet access" (Dhawan, 2020). According to our reckoning, this wording is simple, lapidary and reflects best the concept of the phenomenon.

Contemporary researchers and educationalists often notice and underline the advantages of online learning driven by multimedia technologies as the main teaching instrument. They offer wide resource opportunities and, with their rational usage, the educational process becomes more problem-solving and exploring. Providing online learning, new educational environment is implemented by using different materials from one side and organizing the interaction of the participants from the other side (Khazakova, 2015).

This system has certainly the bulge on traditional teaching methods: individualization of learning, intensification of students' independent cognitive activities and extending teaching practice. These technologies undoubtedly improve the teaching quality and offer to the academic community new opportunities we should know how to use. There are only a few 
examples: close contact between students and teachers (almost 24/7); more complex and creative approach to the educational process as the participants have access to huge repositories of teaching and learning materials; and more independence for students to organize their work and manage their time for studies. The materials chosen by the teachers are received by the students in a qualitative and, what is more important, a re-playable form; pre-prepared webinars or online lecture records can be listened to and revised one more time; and the students can download multimedia presentations on their devices and look them through as a part of their preparation to the midterm or final exams. Actually, there is no more problem of gaps and ill-conceived themes caused by absence from lectures.

However, even the most full-designed courses will not make a difference for students that are not motivated to study. Here, in our research, we talk about students motivated for a sound academic background and analyze objective causes that disturb this process.

\section{DISCUSSION}

COVID-19 pandemic has become a serious challenge for global education systems and has demonstrated the necessity to insert online platforms in all aspects of the educational process and adapt ways of teaching (Boling et al., 2012; Bryson \& Andres, 2020). Many universities have been obliged to design, buy and adopt online learning platforms in a short time frame, so that learning would not be disrupted (Mukhtar et al., 2020), and teachers have been forced to adopt e-learning technologies and establish new ways of communication with their students, often without sufficient instructions, training or resources. Statistics show that almost 1.58 billion children and youth in 200 countries were affected by the pandemic, which is $94 \%$ of learners worldwide (for more information see Policy Brief: Education During COVID-19 and Beyond). This terrifying situation affects everyone connected to the world of education and makes the problem issued in this research more than relevant.

Before we started this research, we had studied similar works in the field published recently in English all over the world, many of them focusing on the technical characteristics of online platforms and the possibilities they offer to their users. For instance, different types of online learning platforms have been named, identified and characterized (Basilaia \& Kvanvadze, 2020). Other researchers have categorized varieties of online platforms into two groups: interactive (facilitator-learner or learner-learner interaction, optional timing and feedback) and non-interactive (less or no provision for interactions, no optional timing). Further, interactive platforms can be asynchronous, synchronous and combined with any non-interactive platform (hybrid). Knowledge-based and online support platforms are typical examples of non-interactive online platforms (Akinyemi, A. L., \& Segun, 2020).

The main aim of the current study is to estimate the technical features and convenience of three online platforms used by three universities. However, every educational field has its specific 
issues that should be taken into account. Several studies have already demonstrated that it is not always easy to organize practical and clinical work, to get immediate feedback and to evaluate students' progress during e-learning (Dhawan, 2020; Mukhtar et al., 2020). Other problem highlighted by the researchers is that sometimes students find online lessons boring and unengaging in comparison with the traditional form (Dhawan, 2020; Mukhtar et al., 2020). In addition, studies report that students are not prepared to keep balance between their work, family, social life and studies within an online learning environment (Dhawan, 2020).

Having analyzed the findings of other studies, which investigate the same topic, we created a list of specific questions and issues to spotlight in our research. What is more, we have considered the human factor while analyzing the adoption of e-learning (see the Results section and Table 2).

To sum up, our study not only investigates the technical features of three e-learning platforms bought or designed by universities in two different countries but also compares various approaches and common mistakes while adopting online learning. We do not pretend pervasiveness in this research, as we base on pieces of practical teaching and learning experience and compare three platforms only, while ignoring other similar widespread technologies. Nevertheless, every experience of this kind requires a careful and detailed analysis, whose final aim is to provide recommendations to all the participants of the e-learning process.

\section{METHODS AND STUDY MATERIALS}

In this research, we used methods of comparative analysis, which include the confrontation and evaluation of the data received, to focus on the experience of three universities (two in Russia and one in Italy), and to trace the adaptive process in an emergency state and the way online learning was adopted on three different platforms. See the details in Table 1:

Table 1

Comparative analysis for confrontation and evaluation

\begin{tabular}{llllc}
\hline \multicolumn{1}{c}{ University } & Country, city & \multicolumn{1}{c}{$\begin{array}{c}\text { Time to adopt } \\
\text { e-learning }\end{array}$} & $\begin{array}{c}\text { E-learning } \\
\text { platform }\end{array}$ & $\begin{array}{c}\text { Mode } \\
\text { of acquisition }\end{array}$ \\
\hline $\begin{array}{l}\text { Dubna State } \\
\text { University }\end{array}$ & Russia, Dubna & 7 days & Google Meet & Purchase \\
$\begin{array}{l}\text { University of } \\
\text { Campania "Luigi } \\
\text { Vanvitelli" }\end{array}$ & $\begin{array}{l}\text { Italy, Campania } \\
\text { region }\end{array}$ & $\begin{array}{l}7 \text { days } \\
\text { (national quarantine } \\
\text { was established on }\end{array}$ & $\begin{array}{c}\text { Microsoft } \\
\text { Teams }\end{array}$ & Purchase \\
& & $\begin{array}{l}\text { March 9 and the first } \\
\text { online lecture was } \\
\text { organized on March 16) }\end{array}$ & & \\
Pyatigorsk State & Russia, & 1-2 days to establish & Edu.pgu & Proprietary \\
University & Pyatigorsk & seamless Internet & & design \\
& & connection & & \\
\hline
\end{tabular}

Own elaboration 
To collect the data, we used interviews and consultations with teachers, students and experts in IT technologies and online learning of these universities. We asked the experts to evaluate the platform functions and characteristics from the technical point of view, and then asked the users of these platforms, the direct participants of the educational process, to share their experience during the pandemic. Some of the questions to the teachers and students are listed below:

1. Do you find your platform sufficient and comfortable for working?

2. What are the advantages and disadvantages of your online platform?

3. Were you ready to adopt online learning at the beginning of the pandemic?

4. Did you get instructions before using the platform?

5. Were online communication and feedback satisfying?

6. Did you have problems while working on your online platform? If yes, please, give examples.

The technical characteristics of the platforms, the answers to the questions and other information we received during the interviews were carefully analyzed, and the results are presented in the next section.

\section{RESULTS}

In the course of the research, we made a comparative analysis of three online learning platforms: Google Meet, Microsoft Teams and Edu.pgu. We focused on three main features of the platforms, such as price, facilities and technical specifications and restrictions. We suppose these criteria are sufficient to estimate the efficiency of the platforms. For the facilities, we chose the following sub-specifications for successful teaching: the possibility to make an online transmission and to record it, the possibility to download additional files and to create and check tests, and the possibility to share your screen. Finally, as the two-way communication is of crucial importance for e-learning, we checked the possibility to send messages and to use online chats within the system.

As for the technical specifications and restrictions, three main sub-specifications were analyzed, including the operating system support, the number of participants for online events and the type of learning (synchronous or asynchronous). Other less indispensable criteria may be added to this list. The results of the research are shown in Table 2. 


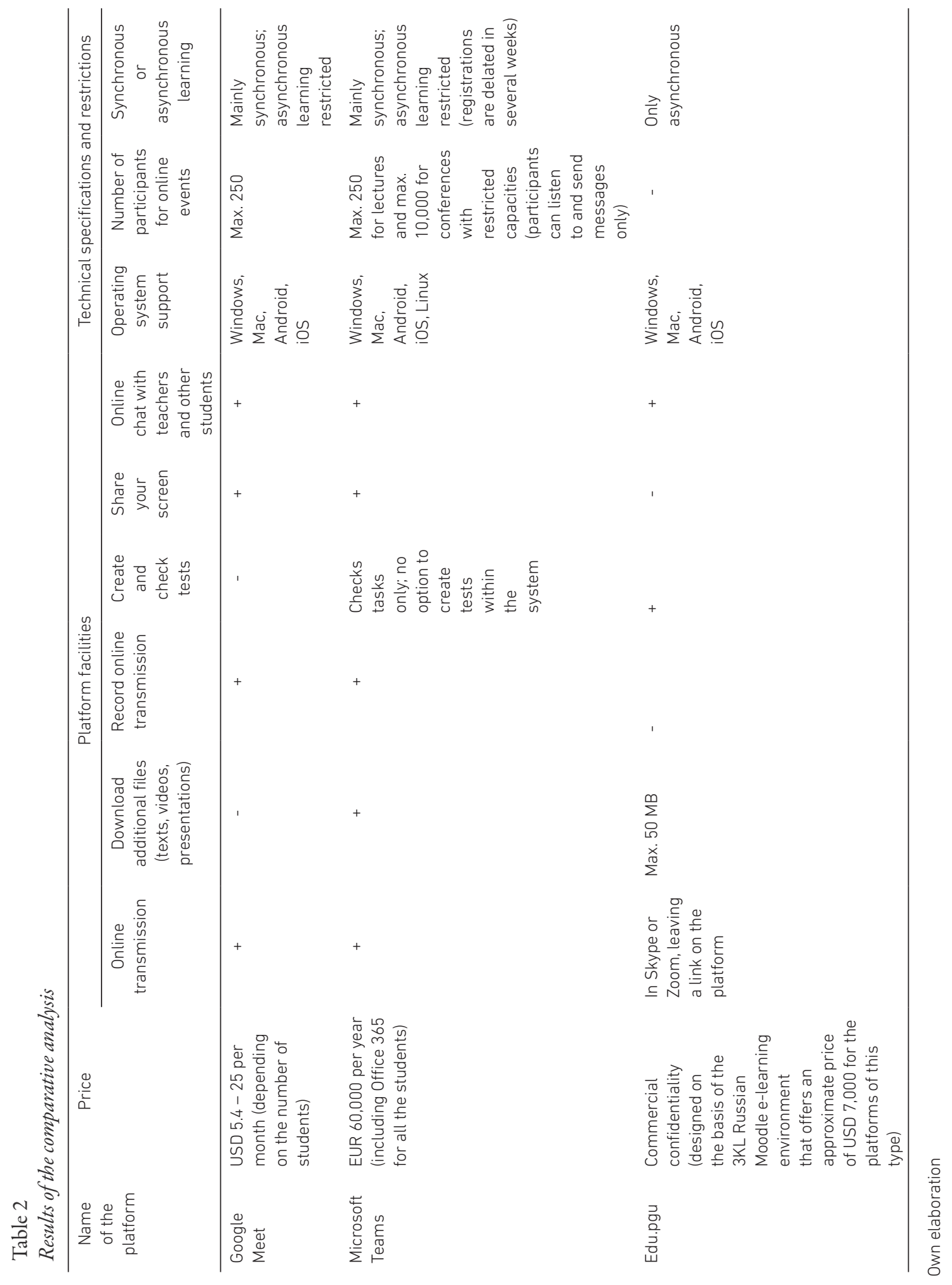


Based on the outcomes of the comparative analysis, we can summarize that all three platforms have advantages, defects and restrictions, which we will detail in the next part of this paper. We would like to emphasize that every online platform is a training device, an instrument that both students and teachers should know how to use. To start with, teachers working with the Edu.pgu system face the problem of the impossibility to establish the authorship of the tasks performed, as the students work by their own and can share their credentials with third persons. It is possible to check written assignments with detailed answer using one of numerous anti-plagiarism systems on the Internet, but it is impossible to establish the authorship of the test cases performed within the system, so that the teachers have to rely on students' honesty.

The lecturing staff of the University of Campania has the same problem. It is hard to check the real attendance and degree of involvement during online lectures, as many students prefer to work with microphones and video cameras off. Therefore, the first time teachers see and become acquainted with their students is during the exams. To ascertain students' identity, teachers have to ask them to show their ID or driving license to the camera, while written exams sent by email are obligatorily accompanied by an ID photocopy. All of these actions might constitute a violation of provisions of GDPR (General Data Protection Regulation for EU countries) and demonstrate dim knowledge of prevailing legislation in the field, regardless of the fact that from March 1 to 31, 2020, during the adoption of online learning, all academic staff and students were following a compulsory course on personal data protection and GDPR.

Another serious problem is the lack of experience and technical skills for working with platforms. Teachers are often incapable of registering lectures, creating presentations, sharing materials, etc. It has been observed that sometimes two-way communication between students and teachers is voluntarily limited or eliminated by one of the participants (by turning cameras, microphones and chats off, or simply by ignoring the messages).

Another drawback of working with platforms is the lack of information on midterm and final exams, such as timetables and exam forms, so the students have to search them on their own or contact the teacher individually.

The academic staff of Dubna State University has faced the problem of partially ignoring the principles of working with the platform, as well as the impossibility to share materials within the system. The way the lectures were performed was controlled by the university administration randomly and by hand. The problem of person identification during the midterm and final exams was off the table because students ought to show their student membership cards to the camera, which is not a violation of the Russian Federal Law on Personal Data.

Despite a huge variety of advantages of e-learning, the factors detailed above significantly deteriorate its quality and make us perceive it of secondary importance in comparison to the "traditional" learning. As a result, students are less motivated and do not develop planning and autonomous activity management skills. 
However, the contest of adopting online learning should be taken into account. Forcemajeure stress situation caused by COVID-19 has made academic staff and students put complicated online instruments into practice and remake whole courses in an extra hurry, just in a few days. The situation was compounded by the total lack of information about the terms of the emergency and the way the midterm and final exams should be done. The precise information on the renewal of offline learning was still missing when this research was conducted.

\section{CONCLUSIONS}

E-learning is comfortable, mobile and economically viable, but at the moment it cannot be considered as a full alternative to the traditional teaching. For full and safety adoption of online learning, the next aspects should be worked out:

- Legal provisions on personal data

- Ways to identify students

- Control over real attendance

- Achievement tests

- Teachers trained to work with online platforms

- Students trained for autonomous work

It is critically needed to resolve these problems for full adoption of a new form of learning. The criteria listed above should be satisfied with joint efforts of government institutions, academic staff and students.

Proceeding from this research, the list of functions for online platforms was prepared to make them comfortable for students and teachers. The list below may be useful for universities that want to buy or design a platform. Check this list of recommended services for online learning platforms:

- Online meeting planning with a reminder (calendar)

- Online meetings

- Online meeting recorder

- Downloading pre-prepared video lectures and events

- Sharing files on the platform (texts, table editors, presentations, etc.)

- Different forms of assessments, such as tests, detailed answers, with a number of efforts and passing scores programmed 
- Opportunity to use platforms with PC, smartphones etc.

- Relatively low device bar for PC, smartphones etc.

We can also offer the following recommendations for universities that want to adopt e-learning systems. Before you start using your platform, please, make sure that:

- the academic staff has followed refresher courses during which they learned to work effectively with the platform. Courses and materials offered by the platform should be used as additional information for refresher courses organized by universities.

- you have prepared simple and available courses on legal provisions in the field of personal data processing (GDPR in Italy and Federal Law on Personal Data No. 152-FZ of July 27, 2006 in Russia). It is extremely important to practice these laws regarding online platforms.

\section{REFERENCES}

Казакова, Т.А. (2015) Использование информационно-коммуникационных технологий в процессе преподавания иностранного языка в вузе. [Электронная версия] \ингвистика и межкультурная коммуникация №3(17) (Journal paper in Russian).

Федеральный закон РФ от 27 июля 2006 года № 152-Ф3 “О персональных данных” (Official text in Russian).

Федеральный закон “Об образовании в Российской Федерации” от 29.12.2012 N 273-Ф3 (последняя редакция) (Official text in Russian).

Akinyemi, A. L., \& Segun M. (2020) Techno-pedagogical Models and Influence of Adoption of Remote Learning Platforms on Classical Variables of Education Inequality during COVID-19 Pandemic in Africa. [Electronic version]. Journal of Positive Psychology and Counselling, 7.72-82.

Basilaia, G. \& Kvavadze, D. (2020). Transition to Online Education in Schools during a SARS- CoV-2 Coronavirus (COVID-19) Pandemic in Georgia. [Electronic version]. Journal of Pedagogical Research, 5(4).

Boling, E.C., Hough, M., Krinsky, H., Saleem, H., \& Stevens, M. (2012). Cutting the Distance in Distance Education: Perspectives on what Promotes Positive, Online Learning Experiences. [Electronic version]. Internet and Higher Education, 15(115). 118-126. doi: 10.1016/j.iheduc.2011.11.006

Bryson, John R. \& Lauren, A. (2020). COVID-19 and Rapid Adoption and Improvisation of Online Teaching: Curating Resources for Extensive Versus Intensive Online Learning Experiences. [Electronic version]. Journal of Geography in Higher Education. doi: $10.1080 / 03098265.2020 .1807478$ 
Dhawan, Shivangi (2020). Online Learning: A Panacea in the Time of COVID-19 Crisis. [Electronic version]. Journal of Educational Technology, 49(1). 5-22. doi: $10.1177 / 0047239520934018$

Mukhtar K, Javed K, Arooj M, Sethi A. (2020). Advantages, Limitations and Recommendations for online learning during COVID-19 Pandemic Era. Pakistan Journal of Medical Sciences. doi: 10.12669/pjms.36.COVID19-S4.2785

Policy Brief: Education during COVID-19 and beyond. AUGUST 2020. Official document of the United Nations.

Regulation (EU) 2016/679 of the European Parliament and of the Council of 27 April 2016 on the protection of natural persons with regard to the processing of personal data and on the free movement of such data, and repealing Directive 95/46/EC (General Data Protection Regulation) (Text with EEA relevance). Official Journal of the European Union. 